\title{
BIRDS OUT MY WINDOW
}

CARMAN DODGE, Box 1933, Prince Albert, Saskatchewan. S6V $6 J 9$

With the changing seasons different species of birds come and go. Over the past five or six years, I have kept track of the birds out my window. The list below does not include all those seen as I know that some ducks and one or two hawks were not recorded:

Common Loon

White Pelican

Double-crested Cormorant

Great Blue Heron

Tundra Swan

White-fronted Goose

Snow Goose

Mallard

Common Goldeneye

Common Merganser

Turkey Vulture

Osprey

Bald Eagle

Golden Eagle

Merlin
Sandhill Crane

Franklin Gull

Ring-billed Gull

Herring Gull

Black Tern

Rock Dove

Common Nighthawk

Barn Swallow

Black-billed Magpie

American Crow

Northern Raven

American Robin

Cedar Waxwing

European Starling

Red-winged Blackbird

Evening Grosbeak

House Sparrow

Okay, you may notice that not many of these are "small" birds, but when you are seven floors up in an office building overlooking the North Saskatchewan River, without the aid of binoculars, the "big" birds will do.

A Pectoral Sandpiper, banded east of Saskatoon on 20 September 1961, was recovered in Yakutia, Russia, on 28 May 1963. In its lifetime it had probably migrated from eastern Russia through the Prairie Provinces to South America and back - at least twice. Houston and Martinez. 1969. Birdbanding 40:146. 